2014

\title{
Waivers of Limitation Periods in the Income Tax Act: Judicial Interpretations and Approaches
}

Sas Ansari

Follow this and additional works at: http:// digitalcommons.osgoode.yorku.ca/olsrps

\section{Recommended Citation}

Ansari, Sas, "Waivers of Limitation Periods in the Income Tax Act: Judicial Interpretations and Approaches" (2014). Osgoode Legal Studies Research Paper Series. 8.

http://digitalcommons.osgoode.yorku.ca/olsrps/8 


\section{OSGOODE HALL LAW SCHOOL LEGAL STUDIES RESEARCH PAPER SERIES}

Research Paper No. 50

Vol. 10/ Issue. 12/ (2014)

\section{Waivers of Limitation Periods in the Income Tax Act - Judicial Interpretations and Approaches}

\section{Sas Ansari}

Editors:

Editor-in-Chief: Carys J. Craig (Associate Dean of Research \& Institutional Relations and Associate Professor, Osgoode Hall Law School, York University, Toronto)

Production Editor: James Singh (Osgoode Hall Law School, York University, Toronto) 
Osgoode Legal Studies Research Paper No. 50

Vol. 10/ Issue. 12/ (2014)

\title{
Waivers of Limitation Periods in the Income Tax Act - Judicial Interpretations and Approaches
}

\author{
Sas Ansari
}

\begin{abstract}
:
The Income Tax Act sets various time limited on actions by the Minister and the Taxpayer. These time limits are there to promote a balance between the need for proper administration of the Act in relation to each taxpayer's affairs and certainty/finality for both the taxpayer and the Minister. One of such time period is the "normal reassessment period" found in section 152. The Act allows for a taxpayer to waive the normal reassessment period, thereby allowing the Minister to reassess the taxpayer beyond this time period.
\end{abstract}

This paper examines waivers of the normal reassessment period in the context of the Income Tax Act, examines the judicial interpretation and application of such waivers, and provides guidance for judges faced with waiver issues.

\section{Keywords:}

Income Tax Act, Canadian Taxation, Tax Administration, Waivers, Statutory Limitation Periods, Judicial Interpretation, Administrative Law working papers series

\author{
Author(s): \\ Sas Ansari \\ Osgoode Hall Law School \\ York University, Toronto \\ E:Sas@sasansari.com
}




\title{
Waivers of Limitation Periods in the Income Tax Act - Judicial Interpretations and Approaches
}

\author{
Sas Ansari*
}

\begin{abstract}
$\underline{\text { Abstract }}$
The Income Tax Act ${ }^{l}$ sets various time limited on actions by the Minister and the Taxpayer. These time limits are there to promote a balance between the need for proper administration of the Act in relation to each taxpayer's affairs and certainty/finality for both the taxpayer and the Minister. One of such time period is the "normal reassessment period" found in section 152. The Act allows for a taxpayer to waive the normal reassessment period, thereby allowing the Minister to reassess the taxpayer beyond this time period.
\end{abstract}

This paper examines waivers of the normal reassessment period in the context of the Income Tax Act, examines the judicial interpretation and application of such waivers, and provides guidance for judges faced with waiver issues.

\footnotetext{
*Sas Ansari is a PhD Candidate at Osgoode Hall Law School, York University. Sas holds an LL.M. from Osgoode Hall Law School, York University, as well as J.D. (with Business Law certification), B.Ed., and B.Sc. degrees from the University of British Columbia..You can view some of his other papers at $h \mathrm{ttp}: / / \mathrm{ssrn}$.com/author=2185221, and view his Canadian case comments at http://ita-annotated.ca/RecentDecisions. Contact him at sasanansari@osgoode.yorku.ca. His current research interests include domestic and international treatment of property, taxation, income, and wealth

${ }^{1}$ RSC 1985 c 1 (5th Supp.) [“ITA”]
} 


\section{Table of Contents}

1. Introduction........................................................................................................ 3

2. Waiver of the Normal Reassessment Period Pursuant to Subparagraph 152(4)(a)(ii) .......... 6

3. Judicial Interpretations of Waivers of Limitation Periods under the ITA ......................... 10

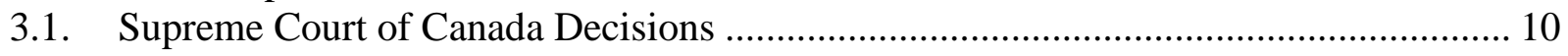

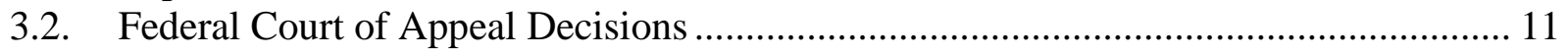

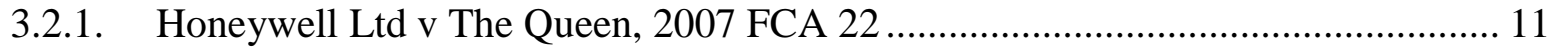

3.2.2. Mitchell v The Queen, 2002 FCA 407 ............................................................ 11

3.3. Federal Court Decisions ..................................................................................... 12

3.3.1. CAL Investments Ltd v Canada, [1991] 1 FC 199 .............................................. 12

3.3.2. Soldberg $v$ The Queen, [1992] 2 CTC 208 (FCTD).......................................... 13

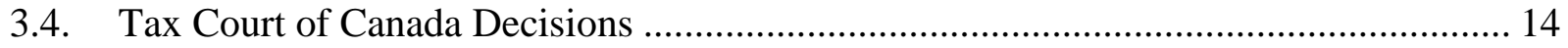

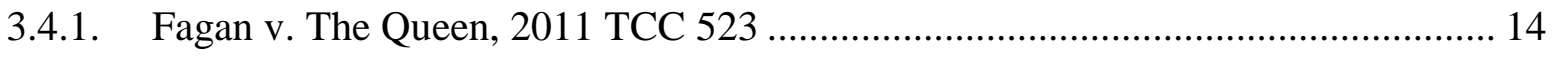

3.4.2. Fietz v The Queen, 2011 TCC 439 ............................................................... 16

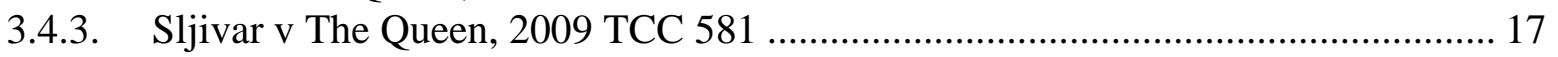

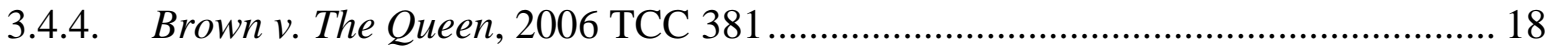

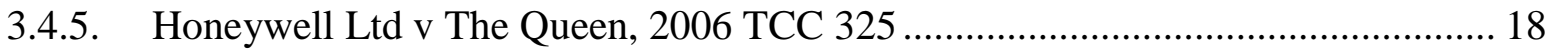

3.4.6. Chafetz v. The Queen, 2005 TCC 803 .............................................................. 18

3.4.7. Holmes v The Queen, 2005 TCC 403 ............................................................ 19

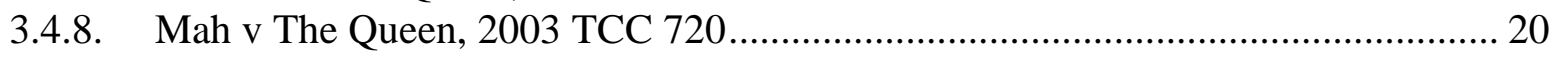

3.4.9. Stone Container (Canada) Inc v The Queen, 1998 CanLII 503 (TCC) ................. 21

3.4.10. Merswolke v The Queen, 95 DTC 821 ........................................................ 22

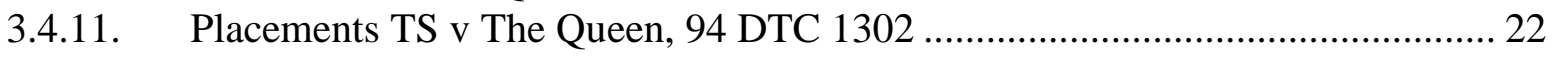

3.4.12. Bailey v The Minister of National Revenue, 89 DTC 416 (TCC) .................... 22

4. Summary of Guidance from the Judicial Decisions ................................................ 23

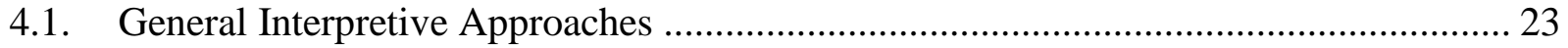

4.1.1. Statutory Interpretive Approach ................................................................... 23

4.1.2. Contractual Interpretive Approach ................................................................ 25

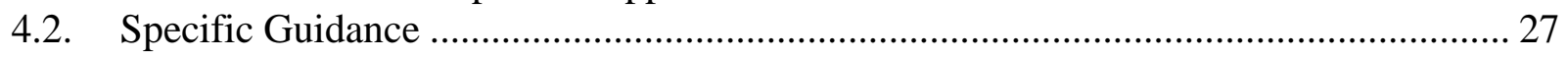

4.2.1. Nature and Purpose of Waiver ................................................................... 27

4.2.2. Connection between the waiver and the reassessment ................................... 28

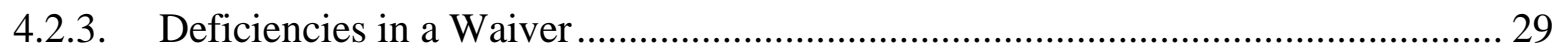

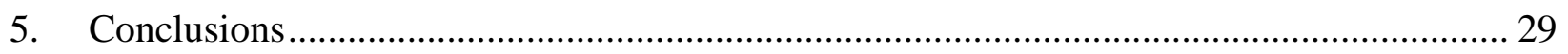


This paper is a Draft, and may contain errors in spelling, grammar, and reference links.

\section{Waivers of Limitation Periods in the Income Tax Act - Judicial Interpretations and Approaches}

\section{Introduction}

The Income Tax Act ${ }^{2}$ sets various time limits on actions by the Minister of National Revenue $^{3}$ as well as the Taxpayer ${ }^{4}$. These various time limits are meant to promote the smooth administration of the ITA, ${ }^{5}$ and to provide a balance between certainty/finality and appropriate flexibility for both the Minister and the Taxpayer. It is important to understand how to navigate the matters that affect these time periods.

An example of the balance between certainty/finality and flexibility is found in Section 152 of the ITA dealing with Assessments. ${ }^{6}$ After a taxpayer has filed the required return(s) of income ${ }^{7}$ the Minister must examine the return(s) of income and assess the tax for the year (including any interest and penalties, if payable, and any refund ${ }^{8}$ or amount deemed paid ${ }^{9}$ ) with all

2 ITA, supra note 1.

${ }^{3}$ Under the ITA, subsection 220(1), the Minister (defined in Subsection 248(1) to mean the Minister of National Revenue) is tasked with administering and enforcing the ITA, and grants the Commissioner of Revenue the power to exercise all of the Minister's powers and perform all of the Minister's duties under the ITA. Further delegation of powers for the purpose of administering and enforcing the Act is allowed under Subsection 220(2.01) of the ITA.

4 "Taxpayer" is defined in Subsection 248(1) to include any "person" whether or not liable to pay tax. "Person" is defined in Subsection 248(1) and reads:

"person", or any word or expression descriptive of a person, includes any corporation, and any entity exempt, because of subsection 149(1), from tax under Part I on all or part of the entity's taxable income and the heirs, executors, liquidators of a succession, administrators or other legal representatives of such a person, according to the law of that part of Canada to which the context extends;

${ }^{5}$ For example see ITA, supra note 1 Subsection 150(1) that sets out the time limits for filing returns of income.

${ }^{6}$ Not all limitation periods will be discussed in this paper. The examples presented have been selected in order to provide an adequate context within which to discuss the judicial approach to, and interpretation of, waivers of limitations periods.

7 The ITA does not require the Minister to wait for a taxpayer to file a return of income. The ITA, in Subsection 152(7), grants the Minister the power to make an assessment notwithstanding any return or information supplied by the Taxpayer or to assess the Taxpayer where no return has been filed. This is often referred to as an 'arbitrary assessment'.

8 ITA, supra note 1, paragraph 152(1)(a).

${ }^{9}$ ITA, supra note 1 , paragraph $152(1)(b)$. 
due dispatch. ${ }^{10}$ With regards to partnership income determinations, the Minister is given the authority to determine the income or loss of a partnership for a fiscal period (or any other amount or matter relevant in determining the tax consequences for any member of a partnership) within 3 years of the latter of two dates. ${ }^{11}$ This, however, does not end the matter for either the Taxpayer or the Minister.

The Minister has the power to "make an assessment, reassessment or additional assessment of tax for a taxation year, interest or penalties, if any, payable under [Part I] by a taxpayer" at any time. ${ }^{12}$ However, this power to assess at any time is limited. ${ }^{13}$ If the Minister wishes to make an assessment, reassessment or additional assessment after the taxpayer's "normal reassessment period"14 for a year, specific exceptions must be satisfied. ${ }^{15}$ There most obvious of the exceptions fall into two general categories. The first general category provides for exceptions where the Minister may (but need not) make an assessment, reassessment or additional assessment at any time. ${ }^{16}$ The second general category includes circumstances where the Minister is required to

\footnotetext{
${ }^{10}$ ITA, supra note 1, Subsection 152(1). Note that the phrase "due dispatch" does not impose a particular time limit on the Minister. Rather, it provides the necessary flexibility for the Minister to proceed with a reasonable assessment, and no fault can be found so long as the Minister acts for the proper purpose of determining the Taxpayer's liability under the ITA: see for example, Ficek v Canada (Attorney General), 2013 FC 502.

${ }^{11}$ ITA, supra note 1, Subsection 152(1.4). See also, the ability to waive the determination limitation period in respect of partnerships in Subsection 152(1.9) of the ITA.

12 ITA, supra note 1, Subsection 152(4).

${ }^{13}$ Note that there are many provisions within the ITA that specify that an assessment can be made by the Minister "notwithstanding subsection 152(4) to (5)". This has the effect of ensuring that there is no limitation period on the Minister's ability to assess. Some examples include: Subsection 69(12) Tax-deferred disposition of property; subsection 143.4(7) deduction of contingent amount; or subsection 67.5(2) Illegal Payments. Additionally, other provisions state that an assessment can be made at "anytime", again expressly denying the existence of a limitation period (see for example subsection 159(3) liability of legal representative).

${ }^{14}$ The "normal reassessment period" is defined in Subsection 152(3.1) of the ITA.

${ }^{15}$ The CRA is of the view that there is no assessment deadline if no initial assessment has been issued (see CRA Document 2001-039945117; see also CRA Document 2013-047650117). This makes sense since in a self-assessing system the tax authority must be given an opportunity to examine a taxpayer's return before a limitation period applies.

${ }^{16}$ ITA, supra note 1, paragraph 152(4)(a). Note, however, that "any time" is limited by subsection 152(4.1) in respect of the exception in subparagraph 152(4)(a)(ii) if the taxpayer files a revocation. Additionally, subsection 152(4.01) provides further limitations on the Minister's ability to make an assessment, reassessment or additional assessment outside of the normal reassessment period.
} 
assess, reassess or additionally assess, but only if the Minister does so before the day that is three (3) years after the expiry of the taxpayer's normal reassessment period. ${ }^{17}$

The first general category of exceptions to the normal reassessment period contains two subcategories. The first subcategory that removes the limitation on the Minister's power to assess, reassess or additionally assess is mean to protect the integrity of Canada's self-filing system. ${ }^{18}$ This power is not penal, but rather remedial. ${ }^{19}$ The limitation of the normal reassessment period is meant to provide diligent and honest taxpayers with certainty/finality with regards to their financial affairs. This certainty/finality is ill-permitted to, and undesirable for, taxpayers or tax filers who have approached their duty(-ies) under the ITA without due care or have deliberately attempted to manipulate the tax consequences attaching to a taxpayer's actions. To prevent taxpayer's from profiting from their dereliction of responsibilities with regards to income taxation, the ITA permits the Minister to assess, reassess or additionally assess a taxpayer or person filing the return ${ }^{20}$ at any time where the taxpayer "has made any misrepresentation that is attributable to neglect, carelessness or willful default or has committed any fraud in filing the return or in supplying any information under" the ITA. ${ }^{21}$

The second subcategory that allows the Minister to assess, reassess or additionally assess at any time, irrespective of the normal reassessment period, is meant to allow for the Minister and the Taxpayer to cooperate in determining the taxpayer's liability/entitlement. ${ }^{22}$ This exception

\footnotetext{
17 ITA, supra note 1, paragraph 152(4)(b).

${ }^{18}$ See for example the comments of the Federal Court of Appeal in Johnson $v$ The Queen, 2012 FCA 253. See also the comments of the Tax Court of Canada in Vine Estate $v$ The Queen, 2014, TCC 64.

${ }^{19}$ College Park Motors Ltd v The Queen, 2009 TCC 409.

20 The phrase "person filing the return" is not meant to capture the listed actions by tax-professionals or taxpreparers that file a return or a taxpayer, but rather to ensure that where a person other than the taxpayer (for example a legal representative) is tasked by the ITA to file a taxpayer's returns, the listed actions by that person allow the Minister to assess, reassess or additionally assess beyond the normal-reassessment period. See Vine Estate $v$ The Queen, 2014, TCC 64.

21 ITA, supra note 1, subparagraph 152(4)(a)(i).

${ }^{22}$ A waiver is seen as a useful and flexible tool for taxpayers in settlements of tax disputes. See Lisa M MacDonell, "Settlement of Tax Disputes at the Appeals and Audit Stage" (2012) Tax Dispute Resolution Compliance, and Administration Conference (Canadian Tax Foundation). See also Bruce Russell, "Assessments, Reassessments and Waivers" (2012) Tax Dispute Resolution Compliance, and Administration Conference (Canadian Tax Foundation).

The courts have recognized that a waiver is beneficial to both the Crown and the Taxpayer (see Cal Investments Ltd $v$ The Queen, 90 DTC 6556. However, some commentators are of the view that a waiver is the exercise of a privilege
} 
operates only on the initiative of the taxpayer or the person filing the return. ${ }^{23}$ Specifically, the ITA allows the Minister to assess, reassess or additionally assess beyond the normal re-assessment period where the taxpayer or person filing the return "has filed with the Minister a waiver in prescribed form within the normal reassessment period for the taxpayer in respect of the year". ${ }^{24}$ This waiver of the normal reassessment period is the focus of this paper.

\section{Waiver of the Normal Reassessment Period Pursuant to Subparagraph 152(4)(a)(ii)}

This portion of the paper will briefly outline and discuss waivers of the normal reassessment period under subparagraph 152(4)(a)(ii). Judicial decisions in regards to such waivers will be discussed in Part 3 of the paper.

A waiver is part of the reassessment process and provides the taxpayer with an opportunity to extend the normal reassessment period when the taxpayer deems it to be advantageous to do so. ${ }^{25}$ As stated, the ability for taxpayers or person's filing a return to waive the normal reassessment period is found in subparagraph 152(4)(a)(ii). ${ }^{26}$ The conditions for a waiver under subparagraph 152(4)(a)(ii) are:

of the taxpayer in favour of the Minister that has the effect of releasing the Minister from statutory time limits (see A Christina Tari, "Waivering" (2002) Canadian Tax Foundation Conference Report 13:1).

${ }^{23}$ The cooperation of the Minister is, to the extent of accepting the waiver, mandatory. The Minister must accept any document containing the required information and must treat it as a waiver. See Mitchell v Canada, 2002 FCA 407, where the court at paragraph 40 stated:

[40] It seems to me that Revenue Canada is obliged to treat any document as a waiver, providing it contains the necessary information. Revenue Canada does not have an option as to whether or not to accept a waiver. A waiver is a privilege which a taxpayer has, and, if sent, Revenue Canada cannot disregard it.

${ }^{24}$ ITA, supra note 1, subparagraph 152(4)(a)(ii). Note that Subsection 152(1.9) allows for a waiver in respect of a determination in respect of a partnership under Subsection 152(1.4). The considerations applicable to waivers under subparagraph 152(4)(a)(ii) apply mutatis mutandis to waivers under subsection 152(1.9), and will not be specifically discussed in this paper.

${ }^{25}$ The advantage to the taxpayer may simply be avoiding an arbitrary assessment by the CRA so as to protect their interest when faced with the expiry of the reassessment period. The Federal Court of Appeal has held that an assessment without any basis other than serving as a protective assessment is valid (see Karda v The Queen, 2006 FCA 238). Similarly, the Tax Court of Canada in Charron v The Queen, [1998] 1 CTC 3096 (TCC) stated at page 3101:

The purpose of a waiver is to continue analysis of a transaction or matter concerning which the basis of the assessment is in question.... The Minister could have assessed immediately since he was still within the normal assessment period.... [F]or the sake of efficiency, it was just as well to accept this mutual accommodation rather than make a hasty assessment, which would not be in the interests of the taxpayer or of the Minister as the administrator of the Act.

${ }^{26}$ The provision reads: 
This paper is a Draft, and may contain errors in spelling, grammar, and reference links.

- The waiver must be filed ${ }^{27}$ by either the taxpayer or the person filing the return; ${ }^{28}$

- The waiver must be filed with the Minister, ${ }^{29}$

- The waiver must be in the prescribed form; ${ }^{30}$ and

152 (4) Assessment and reassessment - The Minister may at any time make an assessment, reassessment or additional assessment of tax for a taxation year, interest or penalties, if any, payable under this Part by a taxpayer or notify in writing any person by whom a return of income for a taxation year has been filed that no tax is payable for the year, except that an assessment, reassessment or additional assessment may be made after the taxpayer's normal reassessment period in respect of the year only if

(a) the taxpayer or person filing the return

(i) $[\ldots]$

(ii) has filed with the Minister a waiver in prescribed form within the normal reassessment period for the taxpayer in respect of the year;

[...]

[emphasis added]

27 The issue of what constitutes "filing" in respect of a waiver was considered by the Tax Court of Canada in Holmes $v$ The Queen, 2005 TCC 403, where the court at paragraph 4 said:

The onus of proving its filing rests with the Minister. Although the Act prescribes the form of the waiver, it does not prescribe the manner in which, or otherwise define how filing is to be achieved; accordingly, whether a waiver has been "filed" will depend on the evidence presented.

${ }^{28}$ A waiver filed by the taxpayer or person who files the return's lawyer or accountant (or other person) authorized by the taxpayer or person who files the return to deal with the CRA has been found to be valid. See Mitchell $v$ Canada, 2002 FCA 407; see also Ackaoui v Canada, 2006 FCA 315.

However, the courts have recognised that a waiver obtained under duress may be invalid (see Guerette v The Queen, [1996] 1 CTC 2780). Also, a waiver obtained by treachery or trickery from a person who did not understand the waiver has been held to be invalid (see Karakas v The Queen, 1995 CarswellNat 1946 (TCC); see also Arpeg Holdings $v$ The Queen, 2008 FCA 31; and Sljivar v The Queen, 2009 TCC 581). To challenge a waiver on the basis of duress, treachery, or trickery declaratory relief must be sought from the Federal Court by making an application for judicial review (see Qureshi v. MNR, 92 DTC 1150 (TCC)).

${ }^{29}$ The cases accept the existence of de facto waivers. One example of a circumstance where, without filing an actual waiver, the Court held there to be a Waiver, was in Mitchell v Canada, 2002 FCA 407. In that case the Minister had agreed with the taxpayer to assess the taxpayer on the basis of the outcome of a test case. The Minister, in a case like Mitchell considers itself to be bound by the agreement, which acts as a waiver. See CRA Doc 2004-0085251E5 where the CRA states:

In circumstances as described in the above paragraph, we are of the view that the Minister would be required to assess or reassess by reason of the agreement entered into between the taxpayer and the CRA, and not by reason of the waiver filed with the Minister.

Another example is a de facto waiver is set out in the CRA Taxation Operations Manual at paragraph 1932.4(2)(B). Where a taxpayer submits a written request for an adjustment, the essential requirements of a waiver are met, the request is made close to the statue-barred date, and if due to work-load constraints the return is statute barred before the assessor has a chance to review it, then the CRA treats the request for adjustment as a waiver.

${ }^{30}$ Although the ITA specifically states that the waiver must be filed in the prescribed form, this is declaratory only (see Cal Investments Ltd v The Queen (1990), 37 FR 250, 44 DTC 6556). The Interpretation Act, RSC 1985 c I-21, at Section 32, deals with the effect of deviating from a prescribed form, and provides:

32. Where a form is prescribed, deviations from that form, not affecting the substance or calculated to mislead, do not invalidate the form used. 
This paper is a Draft, and may contain errors in spelling, grammar, and reference links.

- The waiver must be filed within the normal reassessment period for the taxpayer in respect of the year in respect of which the normal reassessment period is being waived. ${ }^{31}$

Where the taxpayer has filed a valid waiver with respect of a year, the Minister may assess, reassess or additionally assess the taxpayer for that year beyond the normal reassessment period. ${ }^{32}$ However, the ability to go beyond the reassessment period need not be completely open-ended. There are two ways that a waiver can be limited by the taxpayer.

The first way to limit a waiver operates as a limitation on the time-period during which the waiver is valid. ${ }^{33}$ This limitation is effected by filing a revocation of the waiver with the Minister. ${ }^{34}$ Revoking a waiver does immediately end the Minister's power to assess, reassesses or additionally assess outside of the normal reassessment period, but rather limits the Minister's ability to do so by preventing the making of a late assessment, reassessment or additional assessment to before the

Therefore, so long as a document containing all of the required information is filed with the Minister, the Minister must accept it and treat is as a waiver (see Mitchell $v$ Canada, 2002 FCA 407).

31 The Minister does not have the discretion to accept a waiver that is filed after the expiry of the normal reassessment period for the taxpayer in respect of the pertinent year. A waiver filed outside of this period does not permit the Minister on his own or on the request of the taxpayer to reassess beyond the normal reassessment period (See Canadian Marconi Co v The Queen (1991), 51 FTR 159, leave to appeal to SCC refused (1992) 139 NR 395 (SCC); see also Stone Container Canada (Inc) v The Queen, [1998] 3 CTC 2150 (TCC)). However, see the decision of the TCC in Holmes v The Queen, 2005 TCC 403, where the court at paragraph 20 stated that "the power to accept the waiver lies exclusively with the Minister".

In Holmes v The Queen, 2005 TCC 403, the Tax Court of Canada clarified that the Minister bears the burden of proving the filing of a waiver.

Note that paragraph $152(4)(c)$, though intended to apply only to circumstances where a reassessment could otherwise have been issued within the extended reassessment period (see subparagraphs 152(4)(b)(i) to (iv)), could be interpreted as permitting a 3-year blanket extension to the waiver filing deadline. See Michael Kandev, "Changes of Statute of Limitations Should be Welcome to Taxpayers But Contains Technical Glitches" (2009) XV:1 International Tax Planning 1030 (Federated Press).

32 There is no requirement that the Minister actually do anything after the waiver is granted, and there is no limitation as to the number of assessments, reassessments or additional assessments that the Minister may make during the time period where the waiver is effective (See Remillard $v$ The Queen, 2011 TCC 327). However, the Quebec Court of Appeal, in Banque Nationale du Canada v Quebec, 41 No 92 F-120 Droit Fiscal Express (CQ), held that the Minister is only entitled to make one assessment when relying on a waiver.

${ }^{33}$ Absent a revocation, a waiver continues to operate indefinitely. It is for this reason that 'stapled waivers' are used.

34 ITA, supra note 1, Subsection 152(4.1). A revocation is effective in revoking a waiver under subparagraph 152(4)(a)(ii) or Paragraphs 152(4)(c) or (c.1) only. This provision does not contemplate a revocation of a waiver in respect of a determination period filed in respect of a partnership under Subsection 152(1.9). It may be that this is merely a technical oversight, just as recognized by the CRA in respect of the previous absence of a reference to paragraph 152(4)(c) from Subsection 152(4.1); see "Revenue Canada Roundtable" (1987) 47:1 Conference Report 29 , questions 44 and 45. 
This paper is a Draft, and may contain errors in spelling, grammar, and reference links.

day that is six months after the date on which the notice of the revocation in the prescribed form is filed. ${ }^{35}$ There is no statutory provision that allow for the revocation/cancellation of a revocation of a waiver. ${ }^{36}$ However, where the normal reassessment period in respect of a year has not yet expired, another waiver may be filed. ${ }^{37}$

The second way to limit a waiver operates as a limitation on the scope of matters that in respect of which the Minister can make an assessment, reassessment or additional assessment. ${ }^{38}$ This limitation of the scope of matters to which the waiver relates is highlighted in the prescribed form. ${ }^{39}$ The Form contemplates specifying a particular aspect or matter for the relevant taxation year (or taxation years) to which the waiver applies. ${ }^{40}$ The failure to word the waiver sufficiently

35 ITA, supra note 1, Subsection 152(4.1).

${ }^{36}$ See A Christina Tari, "Waivering” (2002) Canadian Tax Foundation Conference Report 13:1.

37 See David W. Smith, "Reassessments, Waivers, Amended Returns, and Refunds," Income Tax Enforcement, Compliance, and Administration, 1988 Corporate Management Tax Conference (Toronto: Canadian Tax Foundation, 1988), 8:1.

38 ITA, supra note 1, Subparagraph 152(4.01)(a)(ii). That subparagraph limits the Minister's ability to assess, reassess or additionally assess outside of the normal reassessment period, when relying on a waiver under Subparagraph $152(4)(a)(i i)$ to the matter specified in the waiver, and reads:

(4.01) Extended period assessment - Notwithstanding subsections (4) and (5), an assessment, reassessment or additional assessment to which paragraph (4)(a), (b), (b.1) or (c) applies in respect of a taxpayer for a taxation year may be made after the taxpayer's normal reassessment period in respect of the year to the extent that, but only to the extent that, it can reasonably be regarded as relating to,

(a) where paragraph (4)(a) applies to the assessment, reassessment or additional assessment,

(i) $[\ldots]$

(ii) a matter specified in a waiver filed with the Minister in respect of the year; and

[...]

Subsection 152(4.01) contains additional limitations applicable to other circumstances. Additionally, the scope of the assessment, reassessment or additional assessment is limits to only those amounts included in computing the taxpayer's income or purposes of an assessment under the ITA, made prior to the expiry of the normal reassessment period in respect of that year, that can reasonably be regarded as relating to a matter specified in a waiver filed in respect of that year.

39 The prescribed from is T2029, "Waiver in respect of the normal reassessment period or extended reassessment period". In the portion of the form tilted "waiver" the person filling out the form is asked to check the appropriate box. The words following the box referring to a waiver under subparagraph 152(4)(a)(ii) reads:

The normal reassessment period referred to in subparagraph 152(4)(a)(ii) of the Income Tax Act, within which the Minister may reassess or make additional assessments or assess tax, interest or penalties under the Act is hereby waived for the taxation year indicated above, in respect of:

$[\ldots]$

[emphasis added]

${ }^{40}$ Note that not specifying a limitation of the scope of matters in respect of which a waiver is filed does not result in a waiver being void (see Fietz v The Queen, 2011 TCC 439). 
This paper is a Draft, and may contain errors in spelling, grammar, and reference links.

narrowly may allow the CRA to issue an assessment, reassessment or additional assessment that is broader in scope than was intended by the taxpayer. ${ }^{41}$ In order to use the limitation in scope and the use of revocations to maximum effect, may consider failing a separate waiver with respect of each separate matter. ${ }^{42}$

\section{Judicial Interpretations of Waivers of Limitation Periods under the ITA}

This paper will not be considering the entire range of judicial decisions that rely on, refer to, or relate to ITA subparagraph 152(4)(a)(ii). Rather, this paper will focus only on the decisions that relate to the scope of a waiver, and therefore to the scope of matters which the Minister may make an assessment, reassessment or additional assessment with respect of outside of the normal reassessment period when relying on a waiver of limitation periods. ${ }^{43}$

\subsection{Supreme Court of Canada Decisions}

The author was not able to find any Supreme Court of Canada decisions dealing directly with the interpretation of a waiver or the determination of the scope of the waiver pursuant to subparagraph 152(4)(a)(ii).

\footnotetext{
${ }^{41}$ For the importance of carefully wording the matters in respect of which a waiver is provided, see Cheryl A Gibson and Daniel V Misutka, "The Art of Resolving Tax Disputes" (2011) Prairie Provinces Tax Conference (Canadian Tax Foundation).

42 See Colin Campbell, Administration of Income Tax 2013 (Carswell: Toronto, ON, 2013).

43 A taxpayer seeking to challenge the contents of a waiver, not to have it nullified because of duress, misrepresentation, trickery, or treachery on behalf of the CRA, falls under the jurisdiction of the Tax Court of Canada. The challenge is brought in the course of an income tax appeal. See A Christina Tari, "Waivering" (2002) Canadian Tax Foundation Conference Report 13:1, where it is written:
}

If the taxpayer seeks to challenge the waiver on the basis of what it says, however, it appears that the Tax Court of Canada has jurisdiction to determine whether the waiver is valid in the context of an income tax appeal. In other words, where, for example, in the course of an income tax appeal the taxpayer challenges the jurisdiction of the minister to assess on the basis that the waiver does not cover the assessing position relied upon by the minister, the issue then before the Tax Court of Canada would constitute a challenge to the validity of the assessment, an issue that this court is empowered to determine. 


\subsection{Federal Court of Appeal Decisions}

\subsubsection{Honeywell Ltd v The Queen, 2007 FCA 22}

In Honeywell, ${ }^{44}$ the Federal Court of Appeal considered the nature of waivers, and at paragraph 32 stated:

32 A waiver when given by a taxpayer and accepted by the Minister gives rise to a bargain of sorts. The taxpayer foregoes the benefit of the normal prescription period for the particular year with respect to the matter specified in the waiver, and the Minister, relying on the waiver, acquires the right to reassess outside the normal assessment period, but only with respect to the matter specified in the waiver. Just as the taxpayer cannot alter the waiver once given, the Minister cannot issue a reassessment that does not reasonably relate to the matter specified in the waiver. As pointed out by Bowman C.J., this is made clear by the language of subparagraph 152(4.01)(a)(ii) which provides that when relying on a waiver the Minister may reassess, "but only to the extent that, [the reassessment] can reasonably be regarded as relating to, ... a matter specified in a waiver filed by the Minister in respect of the year, ...". Accordingly, where a reassessment has been issued pursuant to a waiver, the reference to a "reassessment" in subsection 152(4) can only mean a reassessment as permitted by the waiver.

\subsubsection{Mitchell v The Queen, 2002 FCA 407}

In Mitchell $^{45}$ the taxpayer had, through his lawyer, come to an agreement with Revenue Canada to have the appellant assessed on the basis of the outcome of a test case. Revenue Canada stated that it could not reassess the taxpayer because the taxpayer had failed to file a waiver in the form required under the ITA. The taxpayer's lawyer had sent all the required information called for in a waiver in a letter to Revenue Canada prior to the expiry of the normal reassessment period.

The Court referred to cases where the Minister had argued that waivers were valid despite containing errors. In Gestion B. Dufresne Ltée $e^{46}$, the waiver referred to the wrong taxation year. The court in that case held that the error was a "careless mistake" that did not invalidate the waiver. In Placements T.S. Inc. ${ }^{47}$ there was a discrepancy between the contents of the waiver and the issue under appeal (waiver related to the land and the assessment related to the building), but despite

\footnotetext{
${ }^{44}$ Honeywell Ltd $v$ The Queen, 2007 FCA 22.

${ }^{45}$ Mitchell v The Queen, 2002 FCA 407.

${ }^{46}$ Gestion B. Dufresne Ltée v. the Queen (1998), 98 D.T.C. 2078.

47 Placements T.S. Inc. v. The Queen, [1994] 1 C.T.C. 2464, 94 D.T.C. 1302.
} 
this substantive error in the waiver it was held to be valid as the "taxpayer was not surprised by the assessment [and the] reassessment reasonably related to the mater for which the waiver was issued". ${ }^{48}$ In Solberg, ${ }^{49}$ the waiver referred only to Part III tax while the reassessment concerned Part I tax. The Federal Court held that reference to Part III was a mistake and a technical defect that did not impair the substance of the waiver. The Court held that "[ $\mathrm{t}]$ he appropriate approach to the interpretation of the waiver is to seek to ascertain the intention of the parties as expressed in that document together with any relevant circumstances for which evidence is available", and in this case the surrounding circumstances together with the text of the waiver as a whole demonstrate that both parties knew what was at issue..$^{50}$

The FCA stated that "the Crown was unable to demonstrate any prejudice by the actions of the appellants [, had] notice of all relevant and necessary facts from the beginning when it agreed to reassess on the basis of the test case, [had received letters] contain all of the information to which Revenue Canada was entitled by way of waiver[, and was merely seeking] to avoid on [a] technicality the terms of an agreement which it now admits it had entered into". 51

\subsection{Federal Court Decisions}

\subsubsection{CAL Investments Ltd v Canada, [1991] 1 FC 199}

The Federal Court, in Cal Investments, ${ }^{52}$ spoke about the nature and purpose of waivers of limitations periods under the ITA. It stated, at pages $213-14$ :

A waiver of the sort at issue in this case, might be interpreted as an accommodation between the Crown and a taxpayer for the better administration of the Income Tax Act and to provide a more efficient determination of any liability thereunder. In the light of the limitations on assessments under s. 152 of the Act, the Crown requests a waiver so that it may continue its assessment or audit work in a normal administrative mode without having to worry about limitations. The taxpayer, on the other hand, knows full well that on an assessment being made, he alone has the burden of proving it wrong. That burden becomes much heavier if the Crown, facing the end of the limitation period, issues what might be termed a premature assessment which, for purposes of abundant caution, would include

\footnotetext{
${ }^{48}$ Mitchell $v$ The Queen, 2002 FCA 407 at para 36.

${ }^{49}$ Solberg (S.J.) v. Canada, [1992] 2 C.T.C. 208, 92 D.T.C. 6448

50 Mitchell $v$ The Queen, 2002 FCA 407 at para 37.

${ }^{51}$ Mitchell $v$ The Queen, 2002 FCA 407 at para 43.

${ }^{52}$ CAL Investments Ltd $v$ The Queen, [1991] 1 FC 199.
} 
many sundry items which the taxpayer would have to traverse one by one. The taxpayer in those circumstances would look upon a waiver as being to his own benefit as well as the Crown's and would ordinarily comply with the Crown's request.

In many cases, also, the waiver might be limited to specified issues, i.e., those where assessing or auditing processes have not been completed and which in fact remain the only outstanding items on which the Crown can ultimately decide to assess or reassess. This narrows the field of the assessment and again provides mutual advantages to both the Crown and the taxpayer.

Furthermore, the court outlined the special nature of waivers under the ITA, and stated at page 217-18:

A further element in the matter before me is that this waiver, however prescribed in its form, is not a statutory obligation imposed on a taxpayer over which, in appropriate cases, statutory defences might be raised. A waiver, as prescribed in this case, is no more, no less a consensual arrangement between the taxpayer and the Crown to accept a delayed process for an assessment to be made for reasons which are mutually advantageous.

\subsection{2. $\quad$ Soldberg $v$ The Queen, [1992] 2 CTC 208 (FCTD)}

In Soldberg, ${ }^{53}$ the court was faced with determining whether the reference in a waiver to Part III tax had the effect of invalidating a reassessment in respect to Part I. The Court, at paragraph 13, stated that:

13 Having concluded that the reference in the waiver to Part III was an error, I must then consider whether the waiver is invalid for the purposes of reassessing the taxpayer for Part I tax. I am not prepared to so conclude. In my view, the error is a technical defect which does not impair the substance of the waiver. The appropriate approach to the interpretation of the waiver is to seek to ascertain the intention of the parties as expressed in that document together with any relevant circumstances for which evidence is available. This is consistent with the approach taken in interpreting taxing statutes themselves, see, for example, Stubart Investments Ltd. v. The Queen, 1984 CanLII 20 (SCC), [1984] 1 S.C.R. 536, [1984] C.T.C. 294 , 84 D.T.C. 6305 , at pages $315-16$ C.T.C. (D.T.C. 6323 ).

This approach was approved by the Federal Court of Appeal in Mitchell. ${ }^{54}$

\footnotetext{
${ }^{53}$ Soldberg $v$ The Queen, [1992] 2 CTC 208 (FCTD).

${ }^{54}$ Mitchell $v$ The Queen, 2002 FCA 407 at para 37.
} 


\subsection{Tax Court of Canada Decisions}

\subsubsection{Fagan v. The Queen, 2011 TCC 523}

The Taxpayer filed a waiver with the Minister, and had specifically amended the wording of the Minister to limit the waiver to a specific joint venture. The evidence disclosed that the taxpayers had, on the advice of a lawyer, used wording in the waiver to ensure that other ventures were not included in the waiver. The CRA knew of the limitation and did not consider it to be a problem.

The taxpayer argued that although a technical defect in a waiver does not render it invalid, a substantive defect does. The taxpayer also argued that there was no common understanding between him and the Minister.

The Minister " submitted that the appropriate approach is to ascertain the intention of the parties as expressed in the waiver together with any relevant circumstances for which evidence is available; technical defects do not invalidate a waiver where circumstances show that both parties knew what was in issue; given the nature of a waiver, a matter specified in a waiver must involve a substantial issue between the parties, and in determining what is reasonably related to a matter specified in a waiver, the view of an objective observer with knowledge of all the pertinent facts rather than the subjective view of either party is considered reasonable; a waiver provides the benefit of time to both parties; and finally, the purpose of a waiver is to allow the continued analysis of the matter at issue; the description of the matter cannot be expected to be perfect at the stage of drafting the waiver and the reassessment must relate to the transaction or matter which is the source of the disagreement between the parties and concerning which the taxpayer agreed to sign a waiver." 55

The Court agreed that the scope of a waiver must be ascertained by determining the intention of the parties through analysis of the contents of the waiver and the relevant circumstances. ${ }^{56}$ Extrinsic evidence is important in the analysis of the scope of a waiver, with the

\footnotetext{
55 Fagan v. The Queen, 2011 TCC 523 at para 29.

${ }^{56}$ Fagan v. The Queen, 2011 TCC 523 at para 34.
} 
absence of evidence being able to influence the court's decision as strongly as its presence. ${ }^{57}$ Specifically, the court referred to the decision in Brown, ${ }^{58}$ in stating that a waiver is not a contract "whose interpretation must exclude extrinsic evidence [but rather that] relevant surrounding circumstances play an important role in its interpretation". 59

Where there is a complication with a waiver, the courts take an objective or common-sense approach to determine whether the matter specified in the waiver is one that is reasonably related to the matter that was assessed by the Minister. ${ }^{60}$ A reassessment can reasonably be regarded as relating to the matter in the waiver where the taxpayer was not surprised by the basis on which the reassessment was made by the Minister, or where the basis is known to both parties. ${ }^{61}$ In other words, the courts are willing to affirm the validity of the waiver where doing do would not prejudice either party. ${ }^{62}$

In this case, the appellant was not a member of the joint venture specified in the waiver. However, the court held that where the reassessment is "normally connected with or flows from the matter specified in the waiver", the waiver will be valid in respect of the reassessment. ${ }^{63}$ The appellants company was in the joint venture specified in the waiver, and his flow-through expenses of the appellant were normally connected with the matter specified in the waiver.

Additionally, in interpreting the word "participation" in the waiver, the court referred to the definition found in Black's Law Dictionary, 8th Edition, the Oxford Dictionary, and the

\footnotetext{
${ }^{57}$ Fagan v. The Queen, 2011 TCC 523 at para 35. The court referred to various decisions to show the importance of extrinsic evidence in interpreting a waiver. The cases were: Holmes v. The Queen, 2005 TCC 403; Guerette v R, [1996] 1 CTC 2780; Mitchell v The Queen, 2002 FCA 407; Mah v. The Queen, 2003 TCC 720; and Brown v The Queen, 2006 TCC 381.

58 Fagan v. The Queen, 2011 TCC 523 at para 35.

${ }^{59}$ Fagan v. The Queen, 2011 TCC 523 at para 35.

${ }^{60}$ Fagan v. The Queen, 2011 TCC 523 at para 37. The court referred to Bailey v MNR, [1989] 2 CTC 2177 in making this statement.

${ }^{61}$ Fagan v. The Queen, 2011 TCC 523 at para 40.

62 Fagan v. The Queen, 2011 TCC 523 at para 40.

${ }^{63}$ Fagan v. The Queen, 2011 TCC 523 at para 48.
} 
Merriam-Webster Dictionary. ${ }^{64}$ These definitions, taken objectively, were sufficiently broad to capture the appellant's situation and connect him to the matter in the waiver.

Therefore, were the description in the waiver is defective, but the "substantive matter regarding the purpose of the waiver and the reassessment is clear to all parties", the waiver is valid. $^{65}$

\subsubsection{Fietz v The Queen, 2011 TCC 439}

In Fietz, ${ }^{66}$ the parties referred the question of whether the waiver filed with the Minister permitted the Minister to reassess beyond the normal reassessment period. In this case, the waiver did not contain a description of the matters being waived, as the box identifying the matters in respect of which the waiver was being provided had been left blank.

The TCC stated that a waiver is linked to a reassessment by operation of subsection 152(4.01) of the ITA. ${ }^{67}$ The court must always "determine if a specific reassessment can reasonably be regarded as relating to a matter specified in a waiver". ${ }^{6}$

The taxpayer argued that since the waiver form (Form T2029) stated that "in order for a Waiver to be valid, the matter(s) being waived must be specified", and since no matter was specified, the waiver was invalid. The TCC stated that in order to determine the intentions of the parties so as to determine the scope of the waiver. The intention of the parties "can be determined from the form and the surrounding circumstances". ${ }^{69}$ In this case, the bank document was not meaningless given the effort the taxpayer undertook to find, fill out, and send it the document, but rather waived "the application of the normal reassessment period in relation to a proposed reassessment with respect to some matter". ${ }^{70}$ The intention of the taxpayer was to "file a waiver

\footnotetext{
${ }^{64}$ Fagan v. The Queen, 2011 TCC 523 at paras 49-52.

${ }^{65}$ Fagan v. The Queen, 2011 TCC 523 at para 53.

${ }^{66}$ Fietz $v$ The Queen, 2011 TCC 439.

${ }^{67}$ Fietz $v$ The Queen, 2011 TCC 439 at para 6.

${ }^{68}$ Fietz $v$ The Queen, 2011 TCC 439 at para 46.

${ }^{69}$ Fietz v The Queen, 2011 TCC 439 at para 34.

${ }^{70}$ Fietz v The Queen, 2011 TCC 439 at para 34.
} 
in relation to the proposed reassessment as set out in the Proposal Letter". The court held that the waiver in this case consisted of two documents: The waiver form and the Proposal Letter. ${ }^{71}$

In coming to this conclusion, the court noted that no evidence was presented as to the intention of the lawyer, his assistant, or the taxpayer in relation to the waiver, and that none of these individuals testified during the hearing or filed any affidavits. ${ }^{72}$ The court referred to cases that established that where a party bears the evidentiary burden of establishing an issue, a failure to call necessary evidence justified the drawing of an adverse inference. ${ }^{73}$ The Minister bears the onus of proving that the taxpayer singed a waiver in relation to matters at issue in the reassessment, and in this case had established a prima facie case that the intention was to sign a waiver in respect to all matters in the Proposal Letter. The onus of establishing a different intention rests with the taxpayer. The court referred to the lack of evidence in seeking to argue for an alternate intention, therefore indicating that the extrinsic evidence of intention is admissible and relevant.

\subsubsection{Sljivar v The Queen, 2009 TCC 581}

The TCC, in Sljivar, ${ }^{74}$ was required to determine whether a waiver filed by the taxpayer was valid. The taxpayer, an immigrant with limited education, was called into the CRA offices to sign a document. He did not read the document but was told that the document was just "part of the process", and the CRA officer did not contain the nature or content of the document to him. The taxpayer testified that had he known what a waiver was, he would not have signed it.

The court found that the taxpayer was in a hurry and did not even take the precaution of asking what he was signing. Here, unlike the circumstances surround a debtor and creditor, the interest of the Taxpayer and the Minister are not opposite, and the waiver may be just as much to the interests of the taxpayer as the fisc. The court saw the fact that the taxpayer continued to provide the Minister with documents after the expiry of the normal reassessment period as

\footnotetext{
${ }^{71}$ Fietz $v$ The Queen, 2011 TCC 439 at para 48.

72 Fietz $v$ The Queen, 2011 TCC 439 at paras 35-36.

73 The cases referred to were: Bernardi (c.o.b. Bruno's Pizzeria \& Main Street Billiards) v. Guardian Royal Exchange Assurance Co., [1979] O.J. No. 553 at para 28; and Milliken\& Co. v. Interface Flooring Systems (Canada) Inc., 251 N.R. 358, [2000] F.C.J. No. 129 (FCA).

${ }^{74}$ Sljivar v The Queen, 2009 TCC 581.
} 
evidence that the waiver was serving its purpose: "to permit the taxpayer to provide additional information to prevent the proposed assessment." ${ }^{75}$ There was no evidence of trickery on the part of the Minister, and the waiver was held to be valid.

\subsubsection{Brown v. The Queen, 2006 TCC 381}

The court in Brown ${ }^{76}$ specifically dealt with the relationship of a waiver under the ITA and a contract. The court, at paragraph 26 , clarified that a waiver is not to be interpreted in the same manner as a contract and stated:

26 In my opinion, a waiver is not a contract between a taxpayer and Revenue Canada, excluding extrinsic evidence as to its interpretation. Quite the contrary. Relevant surrounding circumstances are important to determine whether a subsequent reassessment falls within the stated terms of a waiver.

\subsubsection{Honeywell Ltd v The Queen, 2006 TCC 325}

The TCC, in Honeywell, ${ }^{77}$ interpreted that the word "matter" in subsection 152(4.01) means, and stated that "a "matter" in subsection 152(4.01) means a separate subject matter or a discrete head of taxation". ${ }^{78}$ In this case it was held that a GAAR recharacterization of a foreign affiliate's income as interest received by a parent is a "fundamentally different subject matter or head of taxation, and therefore a different matter" from a FAPI assessment. ${ }^{79}$ It does not matter that the tax consequence of the alternate matter would be the same or similar for the taxpayer.

\subsubsection{Chafetz v. The Queen, 2005 TCC 803}

In Chafetz $^{80}$ the court took a common sense approach to the interpretation of the scope of a waiver under the ITA. Justice Miller stated: ${ }^{81}$

\footnotetext{
${ }^{75}$ Sljivar v The Queen, 2009 TCC 581 at para 33.

${ }^{76}$ Brown v. The Queen, 2006 TCC 381.

77 Honeywell Ltd v The Queen, 2006 TCC 325.

${ }^{78}$ Honeywell Ltd v The Queen, 2006 TCC 325 at para 21.

${ }^{79}$ Honeywell Ltd v The Queen, 2006 TCC 325 at para 21.

${ }^{80}$ Chafetz v. The Queen, 2005 TCC 803, aff'd 2007 FCA 45.

${ }^{81}$ Chafetz v. The Queen, 2005 TCC 803 at para 19.
} 
19 If I am not prepared to accept either party's stated intention of the meaning of the matter specified, it is for me to determine objectively what those words mean. Given the very nature of a waiver, a "matter specified" in a waiver must involve a substantial issue between the parties. As indicated in the oft-cited case of Solberg v. Canada, where both parties know what is at issue, a technical error will not invalidate the waiver. It is also clear (see Mah v. Canada) that the Minister cannot base a reassessment on a substantial issue that is not specified in the waiver. These cases lead me to conclude that, in determining the matter specified, I should seek the substantive issue. This interpretation of "matter" accords with Black's Law of [sic] Dictionary interpretation being "a subject under consideration".

[emphasis added]

\subsubsection{Holmes v The Queen, 2005 TCC 403}

The TCC in Holmes, ${ }^{82}$ held that the matter specified in the waiver filed with the Minister cannot reasonably be regarded as relating to the matter the Minister reassessed on. In order for the Minister to be able to reassess beyond the normal reassessment period in reliance of a waiver, the reassessment must, by operation of subparagraph 152(4.01)(a)(ii), reasonably related to a matter specified in the waiver. This requirement was held to be consistent with the "general principle that the taxpayer must know the basis upon which she is being reassessed". ${ }^{83}$ In determining the scope of the waivers, the TCC referred to a letter between the taxpayer and her accountant, as well as the waiver itself. The waiver stated that it was in respect of "1993 farming business [and employee profit sharing plan", further restricted by an asterisk notation that referred to the matters set out in a specific CRA letter that concerned the adequacy of supporting information in relating the farming operations. ${ }^{84}$

The TCC relied on the decision in Solberg ${ }^{85}$ in stating that it is appropriate to refer to the intention of the parties when determining the scope of a waiver. ${ }^{86}$ In this case, the communications between the taxpayer and the revenue agency only referred to the quantification and verification of the expenses, and there was no indication that this was only a preliminary step in determining the extent to which these expenses would be allowed. The taxpayer's past experience with having

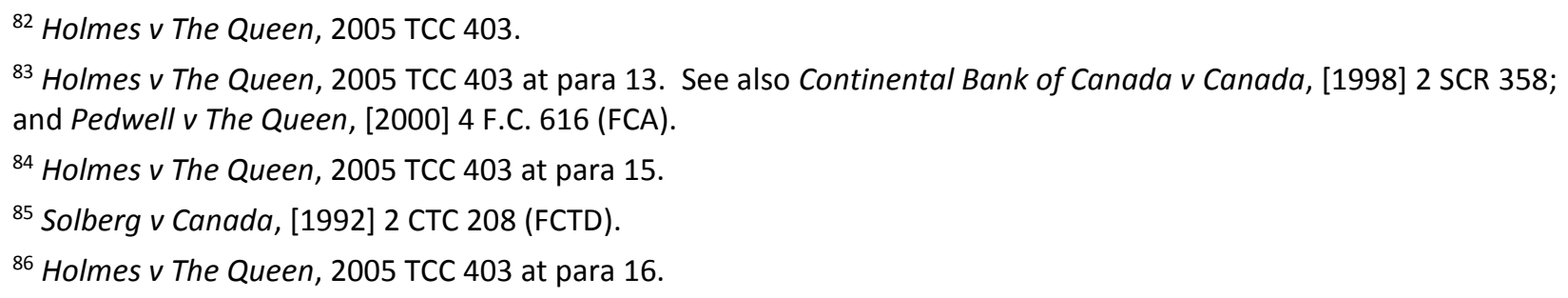


expense denied on the same basis as in the purported reassessment, equally supported the revenue agency's claim that she was aware that the waiver included this issue and the taxpayer's desire to limit the waiver to exclude this issue. The TCC also stated that the contra proferentum rule, and the resultant construction of the documents as against the drafter (the taxpayer as the final drafter), has no application to interpreting the scope of a waiver under the ITA. ${ }^{87}$ As such the court held that the Minister had failed to prove that the waiver extended beyond the verification of the expenses to reach their potential denial.

\subsubsection{Mah v The Queen, 2003 TCC 720}

In $M a h,{ }^{88}$ the taxpayer had signed a waiver that did not refer to any share, but the Minister reassessed to include in income a deemed dividend resulting from a share redemption. The court set out a two stage process in dealing with reassessments and waivers:

[7] In order for me to determine whether the waiver signed by Ms. Mah permits the Minister to reassess under subsection 84(3) of the Act, I must first identify the matter specified in the waiver and, second, decide whether a reassessment under subsection 84(3) can "reasonably be regarded as relating to a matter specified in the waiver".

In this case, in order to identify the matter specified in the waiver, the court had to refer to the language of the waiver and the contents of the letter specifically referred to in the waiver. Subparagraph 152(4.01)(a)(ii) requires a reasonable relationship between the subject matter specified in the waiver and the basis for the reassessment. The court stated at paragraph 13 that "[i]t is quite clear that the Minister cannot base a reassessment on a substantive issue that is not specified in a waiver or cannot be regarded as relating to the substantive issue that is specified in the waiver."

Taxation is transaction based, and in this case the proposed reassessment, and therefore the waiver, referred to the one transaction only. The Minister "cannot reassess on the basis of another transaction, event or circumstance that is not described in the waiver nor is reasonably related to

\footnotetext{
${ }^{87}$ Holmes $v$ The Queen, 2005 TCC 403 at para 19.

${ }^{88}$ Mah $v$ The Queen, 2003 TCC 270.
} 
$\mathrm{it}[$, and a] distinction is to be drawn [...] between a recalculation that necessarily flows from the mechanical application of the Act and a totally separate and unrelated transaction". 89

The court specifically addressed the interpretation of waivers, and stated:

[18] Finally, the Courts have held that in interpreting a waiver, the judge should have regard to the intentions of the parties at the time the waiver was granted [Mitchell v. Her Majesty the Queen., 2002 F.C.A. 407 at paragraph 37]. One should also consider whether the party opposing the waiver can demonstrate any prejudice. In the appeal at bar, the waiver specifically referred to the CCRA's own proposal letter which set out the basis for the proposed reassessment. The letter was written three years after the share exchange and share redemption transactions. Again, the letter does not refer to subsection 84(3) or to the share redemption transaction. I am sure that Ms. Mah had no intention of opening up the share redemption transaction to reassessment under subsection 84(3) when she filed the waiver and it is probable that when the January 21, 2000 letter was written, the Minister did not consider anything other than a possible assessment based on a capital gain.

[footnote deleted; citation and emphasis added]

\subsubsection{Stone Container (Canada) Inc v The Queen, 1998 CanLII 503 (TCC)}

The court referred to the purpose of the waiver and reassessment process, and stated at paras 27 and 28:

[27] The phrase "in respect of" as it is used in the waiver signed by the appellant should not be regarded as wholly limiting the reassessment to the recalculation of the shareholder benefit to the exclusion of all other calculations. To do so would result in the absurd consequence that in having reassessed to include or exclude the shareholder benefit amount, the Minister would then be unable to correspondingly adjust the taxable income, tax payable and other necessarily related amounts. Too narrow a construction of the phrase "in respect of" would render the reassessment process futile, an outcome that could not have been intended by the parties given the very execution of the waiver, and would run counter to the very purpose of a reassessment. On the other hand, nor should the intention be said to have been to grant the Minister boundless authority to reassess -- too broad a construction of the phrase "with respect to" would render the specification of an item in a waiver an equally futile endeavour.

[28] The words "in respect of" in the form of waiver, subject to evidence of a contrary intention, limit the scope of the potential reassessment to (i) the matter specified and (ii) those items the calculation of which necessarily flow from or are immediately connected with the recalculation of the matter in the waiver.

\footnotetext{
${ }^{89}$ Mah v The Queen, 2003 TCC 270 at paras 14-15.
} 
This paper is a Draft, and may contain errors in spelling, grammar, and reference links.

Therefore, the court held that the phrase "in respect of" limited the application related to the matter specified and the calculation for any items that necessarily flow from, or are normally connected to, the matter specified.

\subsubsection{Merswolke v The Queen, 95 DTC 821}

The taxpayer signed a waiver with respect of rental income and expenses related to rental property, and did not refer to capital gains on the disposition of the property. The agreed statement of acts stated that the capital gains realized on the disposition of the property are not reasonably regarded as relating to a matter specified in the waiver.

The court held that a substantive issue not specified in the waiver cannot be relied on by the Minister in supporting an assessment after the normal reassessment period.

\subsubsection{Placements TS v The Queen, 94 DTC 1302}

The taxpayer argued that the waiver referred to a right in respect of property, and that this was a distinct property from the building and the land. The Minister's reassessment related to the disposal of the building and land and not to the disposal of the right of first refusal in respect of the building and land.

The court noted that the purpose of a waiver was to "allow for the continued analysis of a transaction or of a matter where there is uncertainty regarding the basis of the assessment". Given this purpose, the court held that the description of the matter provided in the waiver need not be perfect. As long as the assessment relates to the transaction or matter which is the source of the disagreement between the Minister and the taxpayer, and concerning which the taxpayer signed a waiver, the waiver is valid. The court also noted that it cannot be said that the taxpayer is taken by surprise by the assessment.

\subsubsection{Bailey $\mathrm{v}$ The Minister of National Revenue, 89 DTC 416 (TCC)}

In Bailey, ${ }^{90}$ Justice Rip, as he then was, stated at page 419:

${ }^{90}$ Bailey $v$ The Minister of National Revenue, 89 DTC 416 (TCC). 
A waiver is usually given by a taxpayer to the Respondent when there is an unresolved dispute over one or more specific matters and the three year time period within which the Respondent may reassess is fast approaching. The execution of a waiver avoids a hasty reassessment by the Respondent; it provides the taxpayer with further opportunity to consider adjustments proposed by the Respondent and to allow him to make further representations to support his claim.

In dealing with the interrelation of the word "reasonable" in the phrase "reasonably relate to the matter specified in the waiver", the court stated that reasonable is not the subjective view of either party, but rather "the view of an objective observe with a knowledge of all the pertinent facts". ${ }^{91}$ In determining the scope of the waiver and the meaning of the words used, the court referred to extrinsic evidence, being the negotiations between the taxpayer and the Minister's officers.

\section{Summary of Guidance from the Judicial Decisions}

When it comes to general guidance in how to interpret the scope and content of a waiver of limitation periods under subparagraph 152(4)(a)(ii), the cases above support two alternate approaches. When it comes to specific guidance, however, the cases appear (for the most part) to be consistent. This portion of the paper will first consider the alternate general approaches promoted in the paper, and then will consider the specific guidance offered by the judicial approaches.

\subsection{General Interpretive Approaches}

The two general approaches supported by the cases considered above are the statutory interpretive approach and the contractual interpretive approach.

\subsubsection{Statutory Interpretive Approach}

The comments of the Federal Court in Soldberg ${ }^{92}$ could be interpreted as supporting an interpretive approach to waiver that mirrors that of the approach used for interpreting taxing

\footnotetext{
${ }^{91}$ Bailey $v$ The Minister of National Revenue, 89 DTC 416 (TCC). The court referred to the decision in Canadian Propane Gas \& Oil Limited v MNR, [1972] CTC 566; 73 DTC 5019 in interpreting "reasonable".

92 Soldberg $v$ The Queen, [1992] 2 CTC 208 (FCTD).
} 
statutes themselves. ${ }^{93}$ The Court stated that the "appropriate approach to the interpretation of the waiver is to seek to ascertain the intention of the parties as expressed in that document together with any relevant circumstances", and that this "is consistent with the approach taken in interpreting taxing statutes themselves". ${ }^{94}$ Soldberg is the only decision the author encountered that refers expressly to statutory interpretation when interpreting waivers of limitation periods. ${ }^{95}$

Although intention (specifically the intention of the legislature) is a consideration in statutory interpretation, the involvement of two parties (even if one is a government body) would put the interpretation of intention closer to the contractual camp. That said, the statutory approach is clearly appropriate when giving meaning to the provisions that allow for the creation, functioning, and scope of the waiver. Some of the ITA provisions, particularly those that delineate the scope of the waiver, can be seen as statutory terms that have to be read into the waiver contact. His is similar to the terms that must be incorporated when interpreting various otherwise private contracts such as terms in residential tenancy acts that have to be read into rental agreements, or terms in sales of goods acts that have to be read into various consumer contracts.

The courts have also interpreted terms that are found in the ITA and the form of the Waiver, using dictionaries. ${ }^{96}$ However, this would support both the statutory and the contractual interpretive approaches.

\footnotetext{
${ }^{93}$ Soldberg $v$ The Queen, [1992] 2 CTC 208 (FCTD) at para 13, by reference to the approach to interpreting taxing statutes advanced by the Supreme Court of Canada in Stubart Investments Ltd. v. The Queen, 1984 CanLII 20 (SCC), [1984] 1 SCR 536. contract. These include the statement in Honeywell Ltd v The Queen, 2007 FCA 22 at para 32, that the Minister cannot issue a reassessment that does not reasonably related to the matter specified in the waiver. This is both a limitation and an expansion found in the Act. It is an expansion, when compared to a contractual approach, because it reads into the waiver matters not specified in the waiver, but that a reasonable person would consider to be related to that matter(s) in the waiver. Courts have historically been hesitant, when faced with contracts between private parties, to expand the scope of the contract to include what a reasonable person would have contracted for. ${ }^{96}$ See for example Mitchel $v$ The Queen, 2002 FCA 407.
} 


\subsubsection{Contractual Interpretive Approach}

As stated above, support for the statutory interpretive approach is provided by cases that refer to the nature of the waiver as a "bargain"97, an "accommodation", 98 or a "consensual agreement". 99 Additionally, the dominant approach to interpreting waivers in the case law, the ascertaining of the intention of the parties as expressed in the document of the waiver along with the relevant circumstances, strongly implies a contractual approach to interpretation. ${ }^{100}$ Further support for a contractual interpretive approach is provided by: the taxpayer and the Minister being unable to alter the waiver once given and filed; ${ }^{101}$ basing scope of a waiver on what both parties knew was at issue; ${ }^{102}$ whether a party has suffered prejudice on any of the alternate interpretations; ${ }^{103}$

A. Christina Tari has argued that despite the fact that principles of contract law have often been considered in the context where a waiver is challenged, the law of contract is not technically applicable. ${ }^{104}$ Ms Tari's argument is based on her belief that, in respect of a waiver of limitation periods, a waiver cannot constitute a contract as no mutual consideration is exchanged. She is of the view that it is only the taxpayer that gives consideration in giving up a statutory right, while "no apparent consideration is provided by the Minister when a taxpayer grants a waiver of a

\footnotetext{
97 Honeywell Ltd v The Queen, 2007 FCA 22 at para 32.

${ }^{98}$ CAL Investments Ltd $v$ The Queen, [1991] 1 FC 199.

${ }^{99}$ CAL Investments Ltd $v$ The Queen, [1991] 1 FC 199 at pages 217-18.

100 See Geoff R Hall, Canadian Contractual Interpretation Law, 2nd ed (LexisNexis: Markham, ON, 2012), where the author stated, in Chapter 2, that the fundamental principles of contractual interpretation is to accurately identify the intentions of the parties by considering the words in the contract in light of their context. The author states that a contract cannot be interpreted independent of its context, with context referring to the surrounding circumstances that give rise to the contact. This is the factual matrix within which the contract's words have to be given meaning. See also the decision of the Supreme Court of Canada in Montréal (City) v. 2952-1366 Québec Inc., 2005 SCC 62 ; and in Tercon Contractors Ltd. v. British Columbia (Transportation and Highways), 2010 SCC 4.

101 Honeywell Ltd $v$ The Queen, 2007 FCA 22 at para 32.

102 See Mitchell $v$ The Queen, 2002 FCA 407. This appears analogous to looking at whether there was a meeting of the minds, and what an outside observer would consider to have been the agreement given the words of the agreement and the context.

103 The consideration of prejudice to a party appears to be very similar to circumstances of partial performance in contract law, or the doctrine of promissory estopple. However, this consideration also is similar to considerations of procedural fairness in administrative law, particularly knowing the case to meet and having an opportunity to be heard on the relevant issues/factors.
}

${ }^{104}$ A Christina Tari, supra note . 
This paper is a Draft, and may contain errors in spelling, grammar, and reference links.

limitation period". This interpretation is not supported by either the judicial commentary or the contract law understanding of consideration. It is important to recognise that consideration is for each promise made, and not for the contract as a whole. ${ }^{105}$ To be legally sufficient, there must be something of detriment to the promisor or something of benefit to the promisee, but there is no requirement that there be an offsetting benefit/detriment. ${ }^{106}$ An exchange of promises is sufficient consideration in most cases. ${ }^{107}$

In Honeywell, the Federal Court of Appeal stated that "the taxpayer foregoes the benefit of the normal prescripton [sic] period for the particular year" and the Minister "acquires the right to reassess outside the normal reassessment period, but only with respect of the matter specified in the waiver". ${ }^{108}$ In doing do, the Minister is forgoing the right to make an assessment, within the normal reassessment period, irrespective of any information provided by the taxpayer. ${ }^{109}$ Thus both the Minister and the Taxpayer are foregoing rights, presumably because both see some benefit in doing so. ${ }^{110}$ Either the foregoing of a right, being the suffering of a detriment, or the gaining of a benefit by each party, is sufficient consideration. ${ }^{111}$

However, there are also issues that work against the contractual approach. For example, unlike a contact, the Minister as a party, does not have the option of not accepting a waiver. ${ }^{112}$

\footnotetext{
105 Chitty on Contracts, supra, at para 3-004.

${ }^{106}$ Chitty on Contracts, supra, at para 3-005. The lack of offset only means that a benefit to the promisee is sufficient even if there is no detriment to the promisor, and a detriment to the promisor is sufficient, even if there is no benefit to the promisee.

107 Chitty on Contracts, supra, at para 3-008. It's important to distinguish between "motivation" for making the promise, and consideration for the promise. Motivation cannot serve as consideration.

108 Honeywell Ltd v The Queen, 2007 FCA 22 at para 32.

109 ITA, supra note 1 at subsection $152(7)$.

${ }^{110}$ A benefit for the taxpayer was identified in CAL Investments Ltd $v$ The Queen, [1991] 1 FC 199, where the court stated that a waiver relieves the taxpayer of the greater burden of disproving the Minister's assumptions where the Crown (faced with the expiry of a limitation period) issues a protective reassessment that contains "many sundry items that the taxpayer would have to traverse one by one". In that decision, the Federal Court refers to the "mutual advantages to both the Crown and the taxpayer" in agreeing to a waiver.

${ }^{111}$ The courts, in looking for consideration, are only concerned with the sufficiency of the consideration and not with its adequacy. See Thomas $v$ Thomas (1842), 2 QB 851. See also Chitty on Contracts, $31^{\text {st }}$ edition, Volume I, (Sweet \& Maxwell: London, 2012) paras 3-001 to 3-005.
}

112 See Mitchell v The Queen, 2002 FCA 407. 
Also, unlike a contract, ${ }^{113}$ the courts have held that a technical defect has been held not to impair the functioning of a waiver where the substance of the matter is or ought to have been clear between the Minister and the taxpayer. ${ }^{114}$ The exclusion of the application of the contra proferentum rule, ${ }^{115}$ and the statement that (unlike a commercial lender borrower relationship) the interest of the Minister and the taxpayer are not always in opposition, also challenge the contractual interpretive approach.

Potentially most damaging to the contractual interpretive approach is the statement in Brown, ${ }^{116}$ cited with approval in Fagan, ${ }^{117}$ that a waiver is not a contract "whose interpretation must exclude extrinsic evidence" but rather, in interpreting a waiver, "relevant surrounding circumstances play an important role in its interpretation". ${ }^{118}$ However, the comments in Brown appear to be directed at limiting the application of the parole evidence rule, and promoting the consideration of the factual matrix, rather than a characterization of waivers as something other than a contract. It may be that the court, quite properly, was recognizing the statutory and administrative nature of a waiver, that it the waiver is often a document that refers (directly or impliedly) to matters discussed in other documents, ${ }^{119}$ and that must be given effect in light of its role in administrating the ITA.

\subsection{Specific Guidance}

\subsubsection{Nature and Purpose of Waiver}

A waiver given by a taxpayer and accepted by the Minister is said to give rise to a bargain of sorts, ${ }^{120}$ being a consensual agreement between the taxpayer and the Crown to accept a delay in

\footnotetext{
113 In a contract, where the error effects the substance of the agreement, the courts are unlikely to find an interpretation that give effect to the substance absent a claim of mutual mistake and an application for rectification. 114 Soldberg v The Queen, [1992] 2 CTC 208 at para 13.

115 Holmes $v$ The Queen, 2005 TCC 403.

${ }^{116}$ Brown v The Queen, 2006 TCC 381.

117 Fagan v The Queen, 2011 TCC 523.

${ }^{118}$ Fagan $v$ The Queen, 2011 TCC 523.

${ }^{119}$ See for example the decision in Fietz v The Queen, 2011 TCC 429, where the court held that the blank waiver form and the Proposal Letter together formed the waiver.

${ }^{120}$ Honeywell Ltd v The Queen, 2007 FCA 22 at para 32.
} 
the process for reasons that are mutually advantageous. ${ }^{121}$ This statement supports the contractual interpretive approach to determining the scope of a waiver.

The purpose of a waiver is to allow for the better administration of the Income Tax, ${ }^{122}$ and provide a more efficient determination of the tax consequences attaching to a taxpayer's affairs. ${ }^{123}$ It is meant to give both parties the benefit of additional time to allow for the continued analysis of the maters in dispute and the consideration of additional submissions and evidence. ${ }^{124}$

\subsubsection{Connection between the waiver and the reassessment}

There is a connection between the issue under appeal and the waiver, ${ }^{125}$ such that a waiver must relate to a substantive issue between the parties. ${ }^{126}$ In interpreting a waiver and determining the scope, through identifying the intention of the parties, the courts must always remain cognizant of the fact that a waiver must relate to a transaction or matter that is a source of disagreement between the Minister and the taxpayer. ${ }^{127}$ This connection has led the court to conclude that the word "matter" in subsection 152(4.01) means a separate subject matter or a discrete head of taxation, ${ }^{128}$ being a substantive issue between the parties, ${ }^{129}$ such that the minister cannot reassess on the basis of a transaction, circumstance or event not described in the waiver (or not reasonably related to what is described in the waiver). However, this same connection has also resulted in the court stating that a waiver necessarily includes other issues that necessarily flow from the mechanical application of the ITA, ${ }^{130}$ or that are immediately connected with the recalculation of the matter in the waiver. ${ }^{131}$

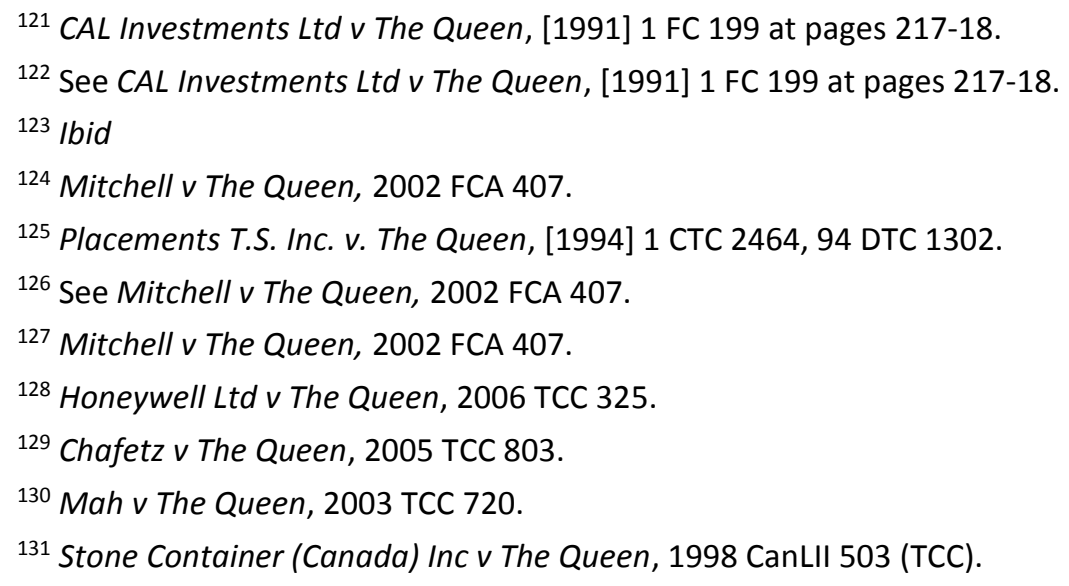




\subsubsection{Deficiencies in a Waiver}

The Courts have held that a waiver is not invalid merely because the waiver contains a technical error that is due to a "careless mistake", ${ }^{132}$ where a substantive error is one that does not result in a reassessment that surprises the taxpayer, ${ }^{133}$ or because there is a technical defect that does not impair the substance of the waiver. ${ }^{134}$ Because the waiver is a document that allows for continued examination in the face of disagreement or uncertainty, the wording of the waiver need not be perfect. ${ }^{135}$ So long as neither party is surprised or prejudiced by the basis of the reassessment, then the waiver is operative despite a deficiency.

\section{Conclusions}

The courts have provided some guidance in interpreting waivers of limitation period sin context of the ITA, but they have not yet provided a comprehensive approach to interpreting waivers. The interpretation of a waiver involves a two-step process: ${ }^{136}$

i. Identification of the matter specified in the waiver; and

ii. Determination of whether the reassessment can reasonably be regarded as relating to the matter specified in the waiver.

In performing those two steps, the courts have to interpret the words of the ITA that delineate the application and scope of the paper, and in doing so they have to resort to principles of statutory interpretation. Given that the waiver incorporates the statutory provisions into itself, the interpretation of the waiver may at times call on the court to resort to statutory interpretation principles hen interpreting the waiver.

That said, the waiver is also a negotiated agreement between the Minister and the Taxpayer, not dissimilar to a contract among private parties. Although some contractual interpretive rules

\footnotetext{
132 Gestion B. Dufresne Ltée v. the Queen (1998), 98 D.T.C. 2078.

133 Placements T.S. Inc. v. The Queen, [1994] 1 CTC 2464, 94 DTC 1302.

134 Solberg (S.J.) v. Canada, [1992] 2 CTC 208, 92 DTC 6448.

135 See Placements T.S. Inc. v. The Queen, [1994] 1 CTC 2464, 94 DTC 1302; see also Bailey v The Minister of National Revenue, 89 DTC 416 (TCC).

${ }^{136}$ Mah v The Queen, 2003 TCC 720.
} 
must be modified to account for the unique statutory and administrative context of waivers in respect to limitation periods in the ITA, contact law principles ought to play an important role in interpreting waivers.

Finally, a waiver is part of an administrative process, thus importing Administrative law principles into the interpretation of waivers.

In interpreting waivers, the courts must be cognizant of the part that the item being interpreted plays in the overall process, and then apply (as appropriate) either statutory or contract law principles, necessarily modified to fit the administrative context of waivers. 